\title{
Reflections on service-learning in european higher education
}

\author{
Álvaro Ribeiro \\ Berta Paz \\ European Observatory of Service-Learning in Higher Education \\ Pilar Aramburuzabala \\ European Association of Service-Learning in Higher Education
}

\begin{abstract}
Over the last two decades, there has been a growing emphasis on the transformation of higher education within Europe. The promotion of active and democratic citizenship through formal higher education is a primary concern. Service-learning (SL) has proven to be a powerful didactic methodology for achieving these ideals. The objective of this paper is to highlight some reflections that permeate SL european experiences, published in the European Observatory of Service-Learning in Higher Education, between January 2020 and September 2021. The counting and percentages of the valued attitudes of SL experiences were collected to explore the guiding philosophy, historical roots, purposes, and underpinning features of $\mathrm{SL}$, contextual factors affecting the practice of $S L$ in the partner institutions and countries, and future challenges and opportunities. Conclusions focus on SL growth and mainstreaming; SL as a core strategic pillar for developing deeper community-higher education partnerships and for strengthening civic engagement across higher education; the need to develop future research to explore these connections and the potential that SL can play in terms of increased civic, work-life and theoretical understandings and skills.
\end{abstract}

\section{Keywords}

Civic engagement, social commitment, social responsibility, democratic citizenship.

Fecha de recepción: 24/XI/2021

Fecha de aceptación: 9/XII/2021

Ribeiro, A., Aramburuzabala, P. y Paz, B. (2021). Reflections on service-learning in European higher education. RIDAS, Revista Iberoamericana de Aprendizaje Servicio, 12, 3-12.

DOI 10.1344/RIDAS2021.12.2 


\section{Reflexiones sobre el aprendizaje-servicio en la educación superior europea}

\section{Resumen}

Durante las últimas dos décadas, ha habido un énfasis creciente en la transformación de la educación superior en Europa. La promoción de una ciudadanía activa y democrática a través de la educación superior formal es una preocupación primordial. El aprendizaje-servicio (ApS) ha demostrado ser una poderosa metodología didáctica para lograr estos ideales. El objetivo de este trabajo es resaltar algunas reflexiones que impregnan las experiencias europeas de ApS, publicadas en el Observatorio Europeo de Aprendizaje-Servicio en Educación Superior, entre enero de 2020 y septiembre de 2021. Se recogieron los recuentos y porcentajes de las actitudes valoradas de las experiencias de ApS, explorando la filosofía rectora, las raíces históricas, los propósitos y las características fundamentales del ApS, los factores contextuales que afectan la práctica del ApS en las instituciones y países socios, y los desafíos y oportunidades futuras. Las conclusiones se centran en el crecimiento y la integración del ApS; el ApS como un pilar estratégico central para desarrollar asociaciones más profundas entre la comunidad y la educación superior y para fortalecer el compromiso cívico en la educación superior; la necesidad de desarrollar investigaciones futuras para explorar estas conexiones y el potencial que el ApS puede jugar en términos de una mayor comprensión y habilidades cívicas, laborales y teóricas.

\section{Palabras clave}

Compromiso cívico, compromiso social, responsabilidad social, ciudadanía democrática. 


\section{Reflexions sobre l'aprenentatge servei a l'educació superior europea}

\section{Resum}

Durant les dues últimes dècades, hi ha hagut un èmfasi creixent en la transformació de l'educació superior a Europa. La promoció de la ciutadania activa i democràtica a través de l'educació superior formal és una preocupació primordial. L'aprenentatge servei (ApS) ha demostrat ser una potent metodologia didàctica per assolir aquests ideals. L'objectiu d'aquest article és destacar algunes reflexions que impregnen les experiències europees d'ApS, publicades a I'Observatori Europeu de l'AprenentatgeServei a l'Educació Superior, entre gener de 2020 i setembre de 2021. El recompte i els percentatges de les actituds valorades de les experiències d'ApS es van recollir per explorar la filosofia rectora, les arrels històriques, els propòsits i les característiques subjacents de I'ApS, els factors contextuals que afecten la pràctica de l'ApS a les institucions i països associats, i els reptes i oportunitats futurs. Les conclusions se centren en el creixement de I'ApS; I'ApS com a pilar estratègic bàsic per desenvolupar associacions més profundes entre la comunitat i l'educació superior i per enfortir el compromís cívic en l'educació superior; la necessitat de desenvolupar investigacions futures per explorar aquestes connexions i el potencial que l'ApS pot tenir en termes d'augment de les competències i habilitats cíviques, laborals i teòriques.

\section{Paraules clau}

Compromís cívic, compromís social, responsabilitat social, ciutadania democrática. 


\section{Introduction}

The purpose of this full paper is to emphasize several reflections that permeate european service-learning experiences, collected by the European Association of Service-Learning in Higher Education (EASLHE), between January 2020 and September 2021. In line with EASLHE's mission of promotion of sustainable human development, this paper aims to address the contribution of service-learning to the development of a culture of political and civic literacy within European higher education. To address it, the authors focused on how such educational organizations are managing the tripartite missions of teaching, researching, and engagement with broader societal issues.

This paper fits this symposium in the thematic axis of sharing and analyzing service-learning experiences and their contribution to the identity and mission of higher education institutions. We hope that this contribution will facilitate exchanges between specialists, authorities, faculty, and students from european higher education institutions on the issues of social commitment and service-learning. The concept of experience is central to servicelearning. It can be considered as:

...a course-based, credit-bearing educational experience, in which students (a) participate in an organized service activity that meets identified community needs and (b) reflect on the service activity in such a way as to gain further understanding of

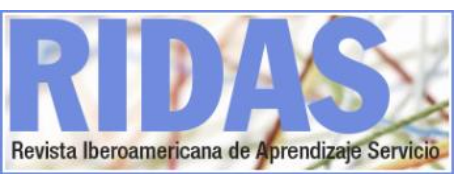

course content, a broader appreciation of the discipline, and an enhanced sense of civic responsibility. (Bringle \& Hatcher, 1995, p.112).

Echoing educational situational concepts like participation, community, and civic responsibility, this definition holds in tension the experiential dimensions of theory and practice, and of individuals and society.

These tensions are rooted in John Dewey's primacy of the concept of experience that connects education and personal experience along an experiential continuum and interaction (Dewey, 1938). Although John Dewey did not specifically call for servicelearning, much can be developed from his works to support it. Since the learnings emerge from or are intrinsic to the act of service, those doing service and those receiving it would undoubtedly learn from the experience. Two immediate implications to servicelearning providers can be placed. The first is that service-learning is ultimately social and communal, and interactive and reciprocal. And consequently, service-learning providers should pay attention to the interaction between who is serving and who is being served, between past and present experiences, and to the transactions that are part of the service-learning experience. By the twenty-first century, these experiences are the ones that carefully integrate the experience of partnering with community members into the overall teaching and learning process. Experiences that foster the development of civic learning skills 
including political knowledge and critical thinking, communication skills, public problem solving, civic judgment, civic imagination and creativity, collective action, coalition building, and organizational analysis (Battistoni, 2013).

In order to ensure the learning derived from the experience of service is rigorous, service-learning should be designed in a way that facilitates the development of those skills as part of, or in addition to, other civic learning objectives. The way to do it seems to be by immersing learners in settings, processes, and interactions in which the concept in question is present and can be critically examined, comparing and contrasting diverse worldviews (Stokamer \& Clayton, 2017). But, to achieve it, more research is needed.

The way to improve the level of social responsibility at university, there is a need to foster in-depth discussion about the role and objectives of the university extension, because, normally, this extension has been outside of the curriculum. It should also be recognized that more insight is needed regarding qualitative and mixed-method designs in order to get a whole picture or to obtain a comprehensive understanding of service-learning. More research is needed to explore the way demographic information from students, faculty, and community partners could potentially interact to influence critical servicelearning outcomes. Many more examples could have been chosen, but these are enough to transmit the notion that, since service-learning is a didactic-pedagogical emergency at the European level, it is however little known at the academic level (McIlrath et al., 2019).

There is a lack of studies contributing to get a better understanding of servicelearning as a phenomenon, and explaining different aspects of its practice, especially across Europe. To face these challenges, one of the methods EASLHE found useful was to disseminate information and knowledge based on service-learning experiences research. In this sense, between January 2020 and September 2021, EASLHE has been mapping servicelearning experiences, with the aim of supporting service-learning research and scientific publications, individual and institutional projects, policy recommendations, and advocating service-learning development in highereducation institutions.

Taking into account the primacy of experience in the context of the pedagogy of civic duty, EASLHE understands that service-leaning is a methodology that immerses participants in experiential learnings that will enhance their democratic education (in terms of political and civic literacy). Such experiential learnings require students to live progressive, humanistic, and radical service-learning experiences (Mtawa \& Nkhoma, 2020). About these experiential learnings, there are entry questions that can be asked and whose answers will help to understand which key tenets students are developing in the context of civic engagement. For example, are European service-learning experiences enabling students to develop awareness and obligation toward society? Is it allowing them to learn and develop 
capacities to solve complex societal issues? Is service-learning achieving the aim of cultivating students' democratic values? Is it enabling students' freedom to choose and act meaningfully? Are service-learning experiences acting as a means to allow students to be proactive and bring about change for themselves and others?

In order to understand the type of experiential learnings European servicelearning projects are addressing, it needs to extract the social meanings elaborated by the actors of the servicelearning practices.

\section{Methodology}

EASLHE is very clear that to answer the above questions, objectivity cannot be achieved by reducing the facts of service-learning activities, but by recognizing their subjectivity.

Therefore, EASLHE assumes the search for answers will be made by confronting the researchers' apriorism with the meanings that the service-learning actors attribute to their actions. For these reasons, the methodology of this work shifts in the interpretive sense, being perhaps more phenomenological as the interest lies in understanding reality in terms of the meaningfulness the actors attribute to the experience.

The research design took place in an emergent way with a low degree of structuring, which consisted of asking respondents, via an online questionnaire, to share with the researchers their brief summaries of the service-learning experience, mentioning the social partner, service, learning objectives and the reflection processes. Still, the respondents uploaded photos, videos, and/or documents in any language, concerning their service-learning experiences.

Still, the respondents uploaded photos, videos, and/or documents concerning their service-learning experiences and did so in various languages. To draw a general profile of the respondents, the questionnaire collected information about their title/position whether they were or not in charge of the servicelearning experience. Information was also collected in terms of the type of institutions surveyed, their ownership, the type of community partners, and the most representative areas of service-learning experiences. For the purpose of this research, the servicelearning experience was defined by the description of a specific practice that took place within one semester or academic year, in which participating students shared common service, learning goals, and evaluation activities. Service-learning experiences occurred at the same time and within the same class or subject.

Full anonymity was maintained, and the completion of the survey was voluntary and unrestricted. Non-probabilistic techniques were used for the selection: the convenience technique, the snowball system, and capture in target places. Two lists of email addresses were compiled and the link to the survey was distributed. The members of the Academic Committee of EOSLHE also filled out the survey regarding their own service-learning experiences and disseminated the questionnaire link through their own contact networks, 
thus operating as satellites across different regions of Europe. The questionnaire was disseminated in international conferences, working as target locations to collect experiences.

The variables in this questionnaire are of the nominal qualitative type and their analysis was performed using percentages and counting of frequencies. As to the brief summaries, a content analysis was made. This content analysis was performed in relation to the constitution, and is, therefore, thematic. It allows access to the social representations shared by service-learning practitioners. For each inducer word, the corresponding induced word was listed.

Simultaneously, new, particular, elements were isolated originating a regrouping of the previous inductive words. In this process, inductive words were not removed, and new ones were not added, as sometimes served as a unit to understand messages, themes, meanings, and objects or referents present in the summaries. With the data and information obtained, it was interpreted in the most plausible and possible way in terms of what may or might be considered transformative. An analysis was made of their association concordant with the operationalization of the concepts, seeking to explain the differences found. This work is fundamental to the subsequent task of interpreting the observed facts and differences. In this research, the authors did not base their work on testing the hypotheses.

\section{Results and discussion}

From January 2020 to September 2021,
EASLHE collected 105 service-learning experiences from 20 different European countries. Those experiences took place between 2017 and 2021. The number of final beneficiaries was 102.248 people, and 7.815 students took part in the experiences. Most of the respondents were academic staff, who were in charge of the service-learning experiences.

The respondents act on behalf of higher education institutions that mostly were universities, more were public (administered by the state), than private (not administered by the state). The universities ran their servicelearning projects based on partnerships established mostly with non-profit organizations. These partnerships were developed in order to implement service-learning projects with the aim of reducing inequalities, improve quality education, good health and well-being.

Following EASLHE's definition of service-learning as an experiential educational method in which students engage in activities addressing real human, social and environmental needs, it is appropriate to appeal to the dimensions of experiential learning in order to address service-learning induced words.

Based on the work of Mtawa and Nkhoma (2020), the researchers understand that it would be congruous to establish a horizontal correspondence between the dimensions of experiential learning, their key tenets, and service-learning practical expressions. Consequently, concepts like responsibility, problem solving, self-actualization, 
development, liberation, and transformation, can play the role of inducing words. In turn, these words are matched by others that represent the most instrumental development of the service-learning experiences. For example, awareness is constitutive of responsibility, valued ends are constitutive of development, meaning is constitutive of liberation.

According to the researcher's analysis of the summaries, it was founded that the most mentioned inducing words were (in descending order) development, responsibility, and problem resolution. Other words such as liberation and transformation were not mentioned in any of the analyzed experiences. In the list of 105 summaries under analysis, around $60 \%$ of the respondents addressed servicelearning issues in the form of development (figure 1). This percentage is markedly higher than that verified with responsibility, which was addressed on $23 \%$ of the projects.

Figure 1. Count of service-learning projects referenced by inducing words

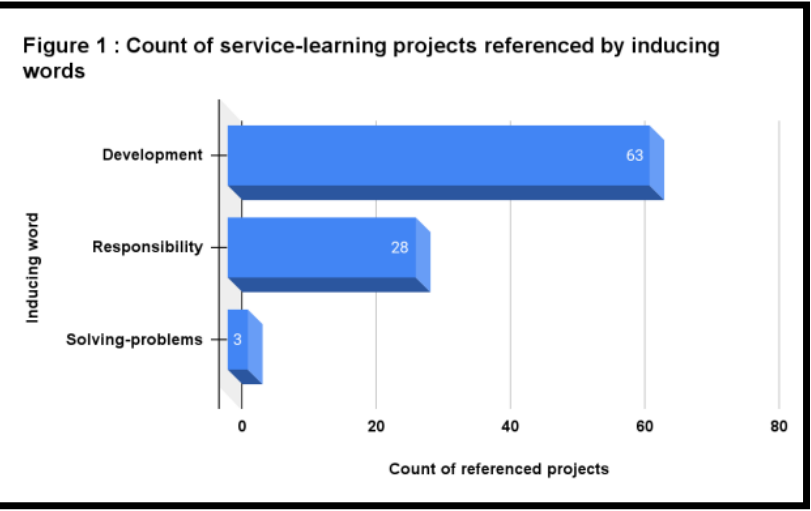

Source: own elaboration
Turning the attention to development issues, European service-learning projects are being designed and implemented focusing most of the time on the development of personal, social, and professional student skills (Table 1 ). These skills need to be learned through education by engaging students as community servers.

Table 1. Correspondence between project development and service-learning practical expressions

\begin{tabular}{|c|c|c|}
\hline $\begin{array}{l}\text { Inducing } \\
\text { word }\end{array}$ & $\begin{array}{l}\text { Inductive } \\
\text { words of } \\
\text { the first } \\
\text { instance }\end{array}$ & $\begin{array}{l}\text { Inductive words of } \\
\text { the second instance }\end{array}$ \\
\hline \multirow{4}{*}{ Development } & Skills & $\begin{array}{l}\text { 1. Employability; } \\
\text { 2. Entrepreneurship \& } \\
\text { Innovation; } \\
\text { 3. Personal \& } \\
\text { Professional Essentials. }\end{array}$ \\
\hline & Community & $\begin{array}{l}\text { 1. Engagement; } \\
\text { 2. Small active; } \\
\text { 3. Local social change. }\end{array}$ \\
\hline & Education & $\begin{array}{l}\text { 1. Reducing poverty; } \\
\text { Increasing quality of life; } \\
\text { 2. Contextual research; } \\
\text { 3. Community service } \\
\text { and engagement } \\
\text { practices; } \\
\text { 4. Learning from positive } \\
\text { examples. }\end{array}$ \\
\hline & Organizations & $\begin{array}{l}\text { 1. Social sphere; Social } \\
\text { services; } \\
\text { 2. Working together with } \\
\text { community partners. }\end{array}$ \\
\hline
\end{tabular}

Source: own elaboration

As service-learning projects are designed by people to serve other people, the development of personal 
and professional skills is central. As for professional skills, European servicelearning projects have been developing communication, teamwork, creativity, good working relationships, mutual agreement. In terms of personal skills, service-learning projects have been promoting empathy, solidarity, a climate of respect and coexistence, and civic commitment. Whether they be personal or professional, they are both taken as learning evidence, ie., behaviours that need to be seen in order for the learning to be acknowledged.

Professional skills channel their development towards entrepreneurial and innovative approaches. Most of these approaches have to do with solutions for the circular economy, new strategies, practices, and policies, organizing agreed activities, efficiently and effectively, and group work. Soft skills channel their improvement towards ethical decision-making, learning by doing, and incorporating a practical and empirical pedagogy into the daily routine.

The predicates of such routines are increased by the development of service-learning contextual research and knowledge exchange (exchanging knowledge), sometimes based on nature itineraries focused on the improvement of the quality of life, reducing poverty and inequalities. Throughout community engagement, service-learning projects foster local social change by researching small active social spheres.

The knowledge resulting from the researcher is exchanged with diverse social partners with whom partnerships are developed. More than enabling students to develop awareness and obligation for society or acting as a way of allowing students to act and bring about change for themselves and others, it seems that universities are running service-learning projects aiming to establish democratic foundations for future achievements in terms of social justice activism, social change makers, and thus fostering the universities' third mission. It seems that more than developing servicelearning projects aiming to participate in and contribute to the policy process, European universities are fostering previous steps in the ladder of empowering students with skills and knowledge to make the change. A service-learning project may be, therefore, a comprehensive socioeducational endeavour, designed in a way that combines research and teaching with civic engagement, continuously negotiating collaborations and partnerships, staying permanently tuned and adapted to personal and social emerging needs and sustainability issues.

\section{Conclusions}

Recognizing the content analysis of 105 brief summaries' subjectivity, it seems that universities have prioritized or become more focused on developing the personal and professional skills of students over community service and on the impact these have on society. Through service-learning projects, students seemed to have had the possibility to enrich, integrate and develop themselves in terms of soft and hard skills, which are seen as valued 
ends. That may mean that servicelearning developed across Europe seems to be used as a didactical methodology for increasing students' capacity on personal reflexivity and community leading and managing. That is to say that through service-learning projects, universities are developing skills and set-practices in the students, having as background guiding philosophies and historical roots, purpose in terms of social responsibility, and democratic citizenship.

\section{References}

Battistoni, R. (2013). Civic learning through service learning: Conceptual Frameworks and Research. In P. $\mathrm{H}$. Clayton, R. Bringle \& J. Hatcher (Eds.), Research on service learning: Conceptual Frameworks and Assessment (2A ed., pp. 111-132). Stylus

Bringle, R.G., \& Hatcher, J. A. (1995). A Service-Learning curriculum for faculty. Michigan Journal of Community Service Learning, 2(1), 112-122.

https://quod.lib.umich.edu/m/mjcsl/32 39521.0002.111?rgn=main; view=fullte $\underline{x t}$

Dewey, J. (1938). Experience and Education. Collier Books.

McIlrath, L., Aramburuzabala, P., \& Opazo, H. (2019). Introduction. In P. Aramburuzabala, L. McIlrath \& $\mathrm{H}$. Opazo (Eds.), Embedding Service Learning in European Higher Education (pp. 7-21). Routledge.
Mtawa, N., \& Nkhoma, N. (2020). Service-learning as a higher education pedagogy for advancing citizenship, conscientization and civic agency: A capability informed view. Higher Education Pedagogies, 5(1), 110-131. https://doi.org/10.1080/23752696.202 $\underline{0.1788969}$

Stokamer, S., \& Clayton, P. (2017). Student civic learning through servicelearning: instructional design and research. In J. A. Hatcher, R. G. Bringle, and T. W. Hahn (Eds.), Research on service learning and student civic outcomes (pp. 45 - 65). Stylus 